\title{
CASE STUDY OF STANDARD MULTI-STOREY \\ RESIDENTIAL BUILDING OWNERS AND TENANTS' PERCEPTION OF BUILDING TECHNICAL CONDITIONS AND RENOVATION ISSUES
}

\author{
Laimdota ŠNĪDERE ${ }^{1}$, Ineta GEIPELE ${ }^{2}$, Iveta STĀMURE ${ }^{3}$ \\ ${ }^{1-3}$ Riga Technical University, Latvia \\ Corresponding authore-mail: laimdota.snidere@rtu.lv
}

\begin{abstract}
The majority of residents in Latvia live in standard multi-storey residential buildings, which were constructed between 1950 and 1992. At present, these buildings are obsolete; besides, in the course of construction process the durability and reliability levels were planned to be insufficient. In Riga, residents of standard multi-storey residential buildings do not support building renovation and are passive, despite the availability of the EU and government support as well as co-financing of building renovation projects. The majority of the respondents assume that the apartment is the most significant asset of the family. Moreover, $34 \%-69 \%$ of the participants have renovated their apartment and save resources within their apartment boundaries. Only some respondents evaluate the technical condition of communal property, but most respondents do not have information concerning resource supply and energy accounting as well as are not interested in resource saving possibilities within the building in general, and do not understand the importance of technical maintenance of the building.
\end{abstract}

Keywords: Building renovation, standard multi-storey residential building.

\section{INTRODUCTION}

On the global scale, the construction industry undergoes profound structural changes: a change in perception of construction industry, new and stricter requirements for environmental protection taking into account energy efficiency, increased attention to the cultural and historical heritage, as well as adaptation to the needs of modern society (Stāmure, Kamola, \& Geipele, 2015).

Before starting building renovation projects, much opposition is encountered in the matter of restoration work; thus, it is necessary to investigate standard residential building owners and tenants' comprehension of the technical condition of buildings and their understanding of the building renovation issues.

Within the framework of the project "Evaluation of the Socio-Economic Values of Impact of Climate Changes and the Flexibility of Adaptation to Climate Changes in Residential Quarters in Riga and Latvia" ("Sustainable Development of MultiApartment Buildings in Riga Micro-Districts"), a survey was conducted with the aim to explore the apartment owners and tenants' understanding of their own 
residence - apartment buildings and architecture, technical equipment, engineering, operations and maintenance, environmental and health issues.

Permanent residents of Riga aged 18 to 74 years were the target group of the survey. Riga is the largest city in Latvia in terms of the number of inhabitants; there are all current standard series of residential buildings.

The survey used quota sampling to determine the number of respondents in this project. The standard group of buildings or a district was selected by random stratified sampling principles - a random principle or a principle of equal opportunities. The survey was based on 3,007 interviews.

To carry out the survey, questionnaires were prepared in the Latvian and Russian languages. Interviews were conducted by highly qualified and specially trained interviewers.

Face-to-face interviews were carried out at respondents' residence using the questionnaire in Latvian or Russian.

There is always some statistical error probability in any research. The differences that belong to the statistical error range can be considered minor (Engel, Jann, Lynn, Scherpenzeel \& Sturgis, 2015). The maximum possible statistical error of the results of 3,007 respondents in a larger sample is $+/-1.8 \%$, which corresponds to the study.

The survey area is standard building districts of Riga, which, in accordance with the zoning stipulated in the project, were divided into 10 areas corresponding to the project specification.

\section{QUANTITATIVE EVALUATION OF STANDARD MULTI-STOREY RESIDENTIAL HOUSING AS A SUSTAINABLE CONSTRUCTION OBJECT IN LATVIA}

Proper administration and management of a multi-storey residential building ensure improvement of the technical condition of the building as well as develop apartment owners and tenants' understanding of the process of saving consumable resources in order to save money and maintain the building in proper technical condition.

The quality of the renovated building (replaced utilities, repaired roof, replacement of windows and entrance doors, insulated walls, etc.) can be improved through works in accordance with sustainable construction standards.

Issues of the nature and role of sustainable construction, which would in turn affect future exploitation of buildings and structures, were examined by scientists such as R. T. Abdulai, F. Obeng-Odoom, E. Ochieng, V. Maliene, H. H. Ali, S. F. A. Nsairat, R. J. Cole, C. K. Chau, M. S. Tse, K. Y. Chung, G. K. C. Ding, I. Geipele, S. Geipele, T. Tambovceva, C. J. Kibert, H. Lavasani, A. Werner, R. Sarsby, T. Meggyes, J. M. Diaz-Sarachaga, D. Jato-Espino, B. Alsulami, D. CastroFresno, etc. (Abdulai, Obeng-Odoom, Ochieng, and Maliene (2016), Ali and Nsairat (2009), Cole (2005), Chau, Tse, and Chung (2010), Ding (2008), Tambovceva, Geipele, and Geipele (2012), Kibert (2012), Lavasani and Werner (2012), Sarsby and Meggyes (2009), Diaz-Sarachaga, Jato-Espino, Alsulami, and Castro-Fresno, (2016)). 
The economic crisis, which most severely hit the economy of Latvia, forced the real estate and construction sectors to purify themselves, improve and think of survival and future development opportunities. Therefore, like elsewhere in Europe, many concepts became topical in the construction sector of Latvia, such as sustainable construction, low-energy consumption buildings or low-energy building, green buildings or green construction, passive houses, lean construction or ascetic, economic construction and others (Stāmure, Kamola, \& Geipele, 2015).

It has been concluded that sustainability is based on the balance of environmental, economic and social issues, thus ensuring balanced development. Sustainable construction is a complex approach to construction projects at the planning, design, construction, installation and maintenance stages, which aim at reducing the negative impact on the environment and improving people's wellbeing. It is a way to live in an environmentally friendly manner, without sacrificing modern comfort and traditional quality standards. Thus, creating a high-quality, environmentally friendly and healthy living space promotes ecological, economic and social sustainability in the future with resulting benefits to any country, including the Latvian environment, society and economy.

The amount of resources in the world reached a critical limit, and it is expected that by 2050 Earth's resources will be depleted. The world population is also increasing disproportionately, and this leads to an increase in the consumption of resources. Many authors indicate a possible lack of resources and their inefficient use in the construction and operation process of buildings, for example, H. H. Ali, S. F. A. Nsairat, R. J. Cole, C. K. Chau, M. S. Tse, K. Y. Chung, G. K. C. Ding, T. Tambovceva, I. Geipele, S. Geipele, etc. (Ali and Nsairat (2009), Cole (2005), Chau, Tse, and Chung (2010), Ding (2008), Tambovceva, Geipele, and Geipele (2012)).

Residents of apartment buildings (standard multi-storey buildings) are among the largest resource consumers. These buildings were built in the last century. They are both physically and morally obsolete, as well as look pathetic - they need major repairs and renovation.

Thus, within the framework of the present research multi-storey residential buildings will be considered.

Regulations No. 1620 “On the Building Classification” as of 22 December 2009 stipulate the classification of buildings by type of use, which ensures a uniform and orderly inventory of structures in Latvia. At the beginning of 2016, in accordance with the register of structures a total of 1,396,964 structures were registered, of which $1,368,258$ or $98 \%$ were buildings, while 28,276 or $2 \%$ were engineering structures.

Analysing the classification of structures that comprises 22 structures by the type of use, it has been found out that in Latvia the highest share belongs to other previously unclassified buildings that account for $59.469 \%$ of the total number of the registered structures. They are followed by single-family houses $(306,295$ or $21.976 \%$ of the total number of the registered structures) and non-residential farm buildings $(84,300$ or $6.048 \%)$. The share of the remaining buildings does not exceed even $3 \%$. In the research, special attention is devoted to multi-storey 
residential buildings. Compared with the previous years, the total number of residential buildings continues to grow in Latvia (see Fig. 1).

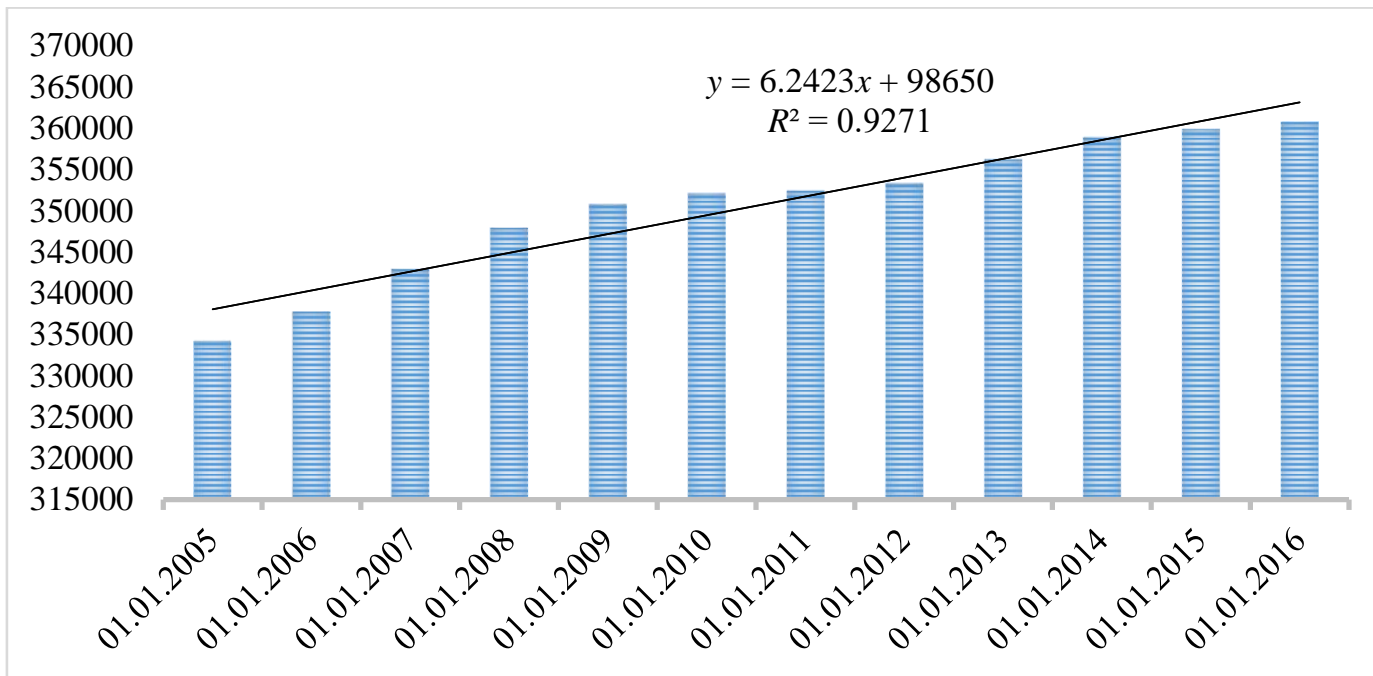

Fig. 1. Dynamics of changes in the number of residential buildings in Latvia [2005-2016], (State Land Service, 2016).

Analysing the available information on the dynamics of the changes in the number of residential buildings in the period from 2005 to 2016 (Fig. 1), it can be concluded that the increase takes place relatively smoothly. Taking into account the nature of time series, the time series of the changes in the number of residential buildings is aligned by means of a linear function and, as a result, the following equation is obtained:

$$
y=6.2423 x+98650, \text { with } R^{2}=0.9271
$$

In conclusion, the number of residential buildings is steadily increasing as demonstrated by the obtained $R$ value.

Analysing the data on residential buildings in Latvia, it can be stated that the main type of buildings is single-family houses amounting to 306,805 or $85.04 \%$ of the registered residential buildings. The next largest group is three- or more-family houses $-39,517$ or $10.95 \%$. In Latvia, two-family buildings are relatively less common constituting 13,751 or $3.81 \%$ of the total number of residential buildings, while houses shared for living by various social groups account for only 663 or $0.18 \%$.

The present research is devoted to the study of three- or more-family residential houses, since they can be classified as standard multi-storey apartment buildings. In Latvia, there are 39,517 standard multi-storey apartment buildings constituting $10.96 \%$ of the total housing stock. This type of buildings can be classified as typical multi-family residential buildings.

Therefore, it is important to find out the opinions of tenants of this particular type of residential buildings on the dwelling they live in, its technical condition, renovation needs as well as clarify their understanding of energy efficiency. 


\section{ANALYTICAL ASSESSMENT OF RESPONDENTS OF TYPICAL STANDARD MULTI-STOREY BUILDINGS}

As already mentioned, before starting building restoration projects, much opposition is encountered in the matter of restoration work because people do not understand the significance of the restoration projects. In order to reveal the individuals' views on the technical condition of buildings and their understanding of the building renovation issues, face-to-face interviews were carried out.

Within the research, it was planned to conduct 7,000 face-to-face interviews. In total, 3,007 interviews were carried out, and 3,993 interviews remained unrealised.

Analysing the reasons for non-response, it should be pointed out that 1,315 respondents were not at home, 800 respondents did not want to answer interviewer's questions, 572 respondents did not have time or other reasons for refusal were mentioned, while 1,306 respondents did not comply with the requirements of the target group.

Within the framework of the research, apartment owners or tenants were interviewed. $66 \%$ of the respondents were owners and $32 \%$ were tenants, 25 respondents did not want to indicate their status. Consequently, it can be assumed that both groups of property users were represented by a fairly large range of respondents.

Assuming that at the age of 18 people have the legal right to make decisions on residential property and building, in which the residential property is located, exactly this age was set as the minimum age of respondents. The largest group of respondents $(25 \%)$ consisted of respondents in the age group of 35-44 years old, $22 \%$ of respondents represented the age group of 25-34 years old, $19 \%$ - a group of 45-54 years old, and $15 \%$ represented a group of 55-64 years old. People of retirement age (65-74 years) represented $8 \%$ of the group, while 18- to 24-yearolds accounted for $3 \%$ of the total number of respondents. $8 \%$ of respondents did not indicate their age.

Analysing the results of the study it can be concluded that all age groups have been represented who have a legal right to make decisions on the improvement of technical condition of the building in order to maintain the building in the proper technical condition.

The authors of the research have recognised the respondents' level of education as an important characteristic of socio-demographic profile.

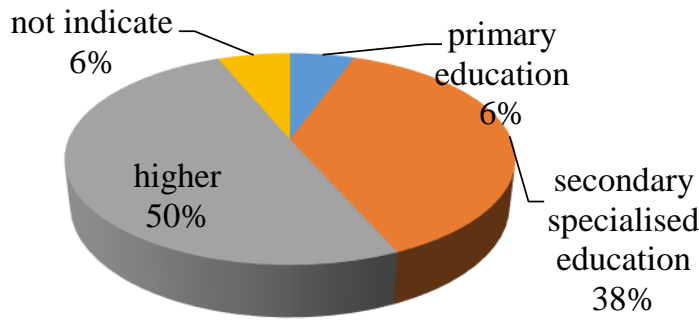

Note: $n=3007$

Fig. 2. Respondents' level of education. 
Analysing the research results demonstated in Fig. 2, it can be concluded that most respondents, or $50 \%$ of the total number of respondents have higher education. By contrast, $38 \%$ of respondents have secondary or secondary specialised (vocational) education. $8 \%$ of respondents have primary education, and $6 \%$ of respondents did not want to indicate their level of education.

Thus, it can be concluded that the study has covered respondents with all levels of education. Main activity of the respondents is the next important characteristic feature.

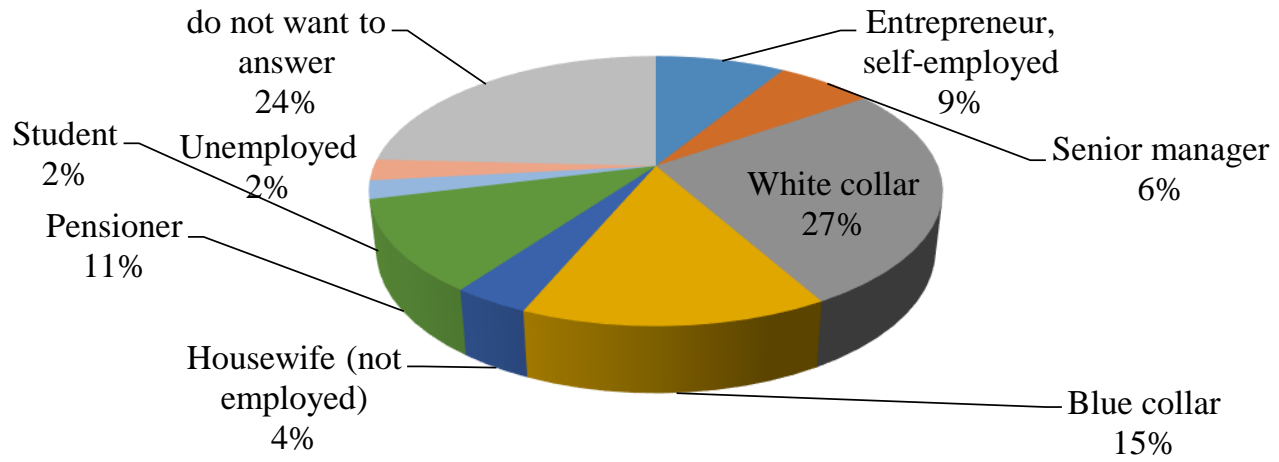

Note: $n=3007$

Fig. 3. Respondents' principal (main activity).

In terms of respondents' main activity, it appears that $17 \%$ of respondents are white collar employees, $15 \%$ - blue collar workers, $11 \%$ - retired, $9 \%$ of respondents are entrepreneurs or self-employed persons, $2 \%$-students, $2 \%$ are unemployed and $4 \%$ are housewifes (unemployed). $24 \%$ of respondents did not want to indicate their main type of acitivity.

Respondents' socio-demographic profile is also characterised by household income per family member. The respondents were also asked to indicate the level of income per family member per month.

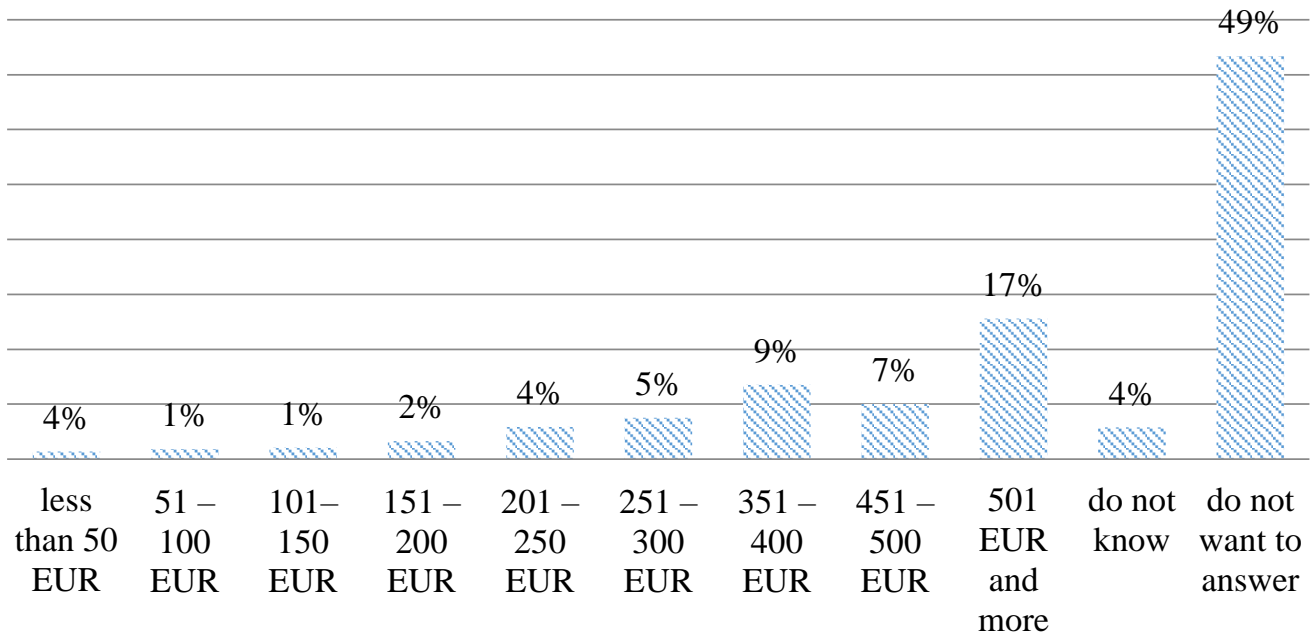

Note: $n=3007$

Fig. 4. Household income per family member per month, EUR. 
Analysing the information provided in Fig. 4, it can be concluded that respondents with different income levels participated in the survey. However, it should be mentioned that a large number of respondents (i.e., $49 \%$ ) did not indicate their income. It should be noted that $33 \%$ of respondents have an income of 351 EUR or more per family member.

By analysing the information on the respondents' age, income, social conditions and other relevant assessment criteria, it can be concluded that the respondents present a broad research area as respondents of different age groups, gender, different income levels, etc., have been represented. Thus, a wide range of respondents suggests that the research is not subjective.

\section{ANALYTICAL ASSESSMENT OF THE ANSWERS OF RESPONDENTS OF STANDARD HOUSING STOCK}

In the sociological survey carried out in March 2016 within the framework of the research, 72 questions were asked, of which more than a half of the questions were related to the management of residential buildings, quality, market value of housing units, technical condition of buildings, repair works carried out, energy saving measures, understanding of energy efficiency improvement measures and attitudes towards the renovation of buildings.

The first set of questions dealt with the issues that were topical for tenants of multi-family residential buildings, i.e., residential building management and satisfaction with the services provided.

The type of apartment ownership is closely related to the remaining residential property of a particular building. In order to ensure the harmonious development of residential property, the apartment owners, on the basis of the existing laws and regulations, as well as mutual decisions, jointly agree on further maintenance, development of the building, efficient use of resources and management.

Residential building management is not only the prevention of accidents or collection of rent and utility payments, but also the process that requires good knowledge and understanding of engineering, financial, psychological and legal issues. In residential building management, it is important to balance the available resources with today's minimal needs, as well as save and accumulate funds for the development of a residential building. (Geipele S., Geipele I., Slava, \& Stamure, 2012).

A professional real estate manager is the right tool in the hands of the owners of apartments to manage a residential building in a qualitative and responsible manner. 


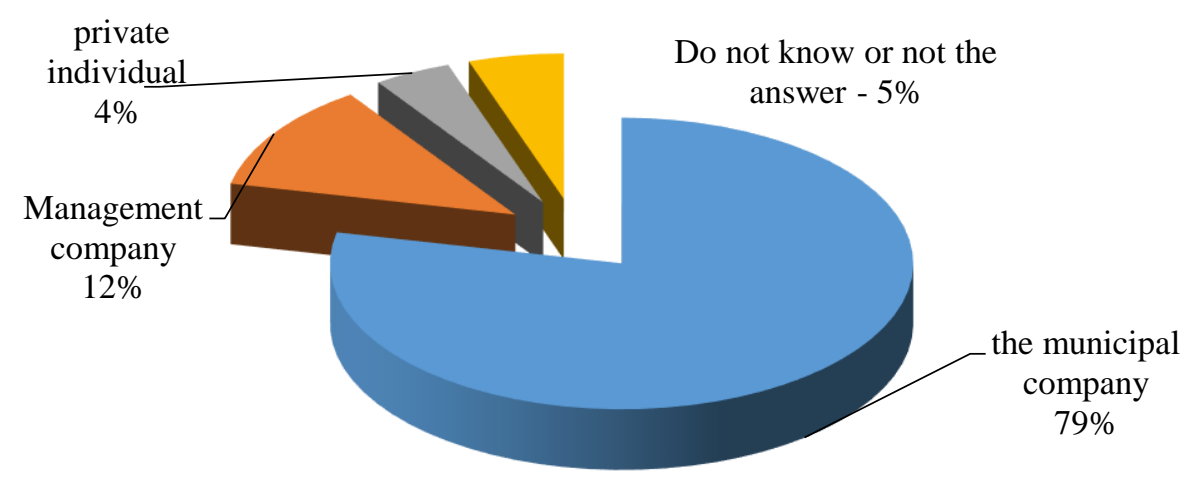

Note: $n=3007$

Fig. 5. The manager of respondents' dwellings.

Most respondents (79\%) live in the buildings, which are managed by the municipal company "Rīgas namu pārvaldnieks", $12 \%$ of respondents mentioned other management companies and only $4 \%$ of respondents - a natural entity as a house-manager. At the same time, $53 \%$ of respondents are satisfied with the current house-manager, $11 \%$ of respondents expressed the desire to change the housemanager, while $36 \%$ did not answer.

The rights and obligations of a multi-family residential building manager are determined in the residential building management contract signed by the residential building owners and the manager. Apart from the rights and obligations stipulated in the contract, they are also laid down in the Law on Administration of Residential Houses and Civil Law. (Legislation of the Republic of Latvia, 2015).

The Law on Administration of Residential Houses has introduced laws and regulations in a regulatory framework - "mandatory management functions to be carried out", which define the duties and responsibilities of apartment owners and managers in terms of building management. These actions are binding for all apartment owners and managers, if they are authorised on the basis of the management contract.

Apart from maintenance of a residential building, a manager should mandatorily carry out the management work planning, organisation and supervision, which includes the preparation of a draft budget for the respective year and the organisation of financial accounting. The procedure of keeping and updating of residential building files is determined by the Regulations of the Cabinet of Ministers No. 908 "Keeping and Updating of House Files" as of 28 September 2010.

The following management activities of a residential building should be carried out in all cases:

- maintenance of a residential building - sanitary maintenance, heating, cold water and sanitation, as well as municipal waste disposal, existing equipment and engineering inspection, maintenance and current repair;

- management work planning, organisation and supervision;

- keeping files of a residential building; 
- enforcement of the minimum requirements for a residential building as an environmental object;

- enforcement of the minimum requirements for energy efficiency of a residential building;

- entering into contract on the use of the settled land with land owners and provision of information to state and local government institutions.

Maintenance of a residential building or natural conservation according to the legal provisions includes sanitary maintenance of a building; household waste collection; engineering inspection; technical state inspection; minimum energy performance assurance and current repair operations; central heating, cold water, sewage provision.

In practice, there are many different examples. Management work during the winter can be mentioned as one of the examples, when the roofs of the buildings require special attention. Over the past few years, snowy winters resulted in the enormous thickness of snow cover on the roofs, which may pose threats to both building constructive elements and life of passers-by. If in the management period special attention is not devoted to proper maintenance of the roofs or there is a lack of resources required for maintenance, the consequences can be fatal and result in criminal liability.

Thus, the authors of the research have come to a conclusion that Article 6 of the Law on Administration of Residential Houses acts as a contributory factor in the management of residential buildings, since it stipulates the obligatory actions to be included in the management of a building and responsibilities of every owner, coowner and manager of a residential building.

Part 3 of Article 6 of the Law on Administration of Residential Houses stipulates that management activities comprise also other activities. Other management activities are activities associated with the management of a residential building and are carried out in compliance with the residential building owner's will and ability to pay. These include residential building improvement and development as well as the activities necessary for the long-term plan preparation.

Other management activities include activities carried out only at the will of a residential building owner but not for the reason that these activities have been determined by law as mandatory obligations. These include residential building improvement and development activities, such as replacement of any tools or utilities with modern ones. Performing other management activities, the law obliges the manager to plan, organise and monitor these activities.

The authors of the research consider that it creates confusion and problems in practice, because it is sometimes difficult to distinguish between mandatory activities and other activities.

Respondents ( $88 \%$ ) stated that the main function to be carried out by the manager was cleaning and improvement of the communal area, which was followed by territory improvement and cleaning $(81 \%)$ as well as keeping a building engineering system in good working order $(74 \%)$.

The next set of questions concerned the issues related to technical maintenance of respondents' apartment and the entire residential building. 
The research results show that the majority of respondents' apartments (82\%) have district heating, and heat is mainly ( $81 \%$ ) supplied by JSC Rīgas Siltums. Hot water supply is provided centrally in most apartments $(81 \%)$, only $15 \%$ of respondents heat water themselves; in most cases $(82 \%)$ electricity is used to heat water, and gas appliances are used by $14 \%$ of respondents. $67 \%$ of respondents' apartments have natural ventilation, $42 \%$ of respondents, apart from natural ventilation, have also exhaust fans in the kitchen, $14 \%$ have the mechanical supply and exhaust ventilation in the building, but $11 \%$ - sanitary node exhaust fans. $67 \%$ of respondents confirmed that they had installed gas meters in their apartments. Most respondents also indicated that they had installed electricity meters (85\%), cold water meters with filters $(64 \%)$ and hot water meters with filters $(56 \%)$. In most cases, an owner of cold and hot water meters is an owner of the apartment, while that of electricity, gas and heat meters - the suppliers of respective services (Latvenergo - 50 \%, Latvijas Gāze - $46 \%$ ).

The research results show that only $13 \%$ of respondents have installed thermostats in their apartments, which allow regulating indoor air temperature. In a similar survey, which was carried out in 2005 , only $5 \%$ of the respondents indicated that they had thermostats in their apartments.

The research results confirm the need for raising owners' awareness not only of their personal property, but also of the entire communal property as a whole.

Analysing the research results on the technical condition of buildings and specific proposals for further action, it should be noted that only $20 \%$ of survey participants believe that the technical condition of the building, in which they live, is good; therefore, there is no need to change anything. The majority of survey participants admit that the technical condition of the building should be improved, and they identified the need for cosmetic repair of stairwells and facades $(35 \%)$. In their turn, $24 \%$ of respondents consider that the buildings should be renovated, including insulation and window replacement, which require additional investment.

According to respondents' opinions, three most important elements influencing the value of an apartment are heating and water supply system (63\%), technical condition of windows $(59 \%)$; more than a half of the respondents also mentioned the drainage system and the condition of entrance door of the building (38\% and $58 \%$, respectively). The respondents also mentioned the storm water system (39\%) and the existence of an elevator (36\%) as the components determining the value of an apartment. It should be noted that $17 \%$ of respondents did not answer the question.

The next set of questions was dedicated to improvements made in the owner's property - an apartment. The survey results show that some respondents made cosmetic repairs (34\%), $21 \%$ of them made it 2-5 years ago, while others changed plumbing fixtures (59\%): faucets, sinks and sanitary system (water boxes).

The question then arises whether people are aware of the market value of their apartment, as well as of the sources from which the information can be obtained. More than a half $(67 \%)$ of the surveyed tenants of multi-family residential buildings admitted that they do not follow the market value of the apartment, while $22 \%$ of apartment dwellers take an interest in it. In terms of the source of 
information about the market value of the apartments, $96 \%$ of apartment dwellers, who monitor the market value of apartments, get information from press advertisements; $40 \%$ of respondents find the necessary information on the specialised websites for housing market participants and brokers, and $12 \%$ of the residents call or meet with the competent representatives of the housing market.

Less than a half or $47 \%$ of apartment dwellers do not want to pay higher monthly payments during the period of five to fifteen years in order to invest in the technical improvement of the building and increase the market value of the apartment, $28 \%$ of survey participants would be willing to settle such payments, and $25 \%$ of respondents replied with "difficult to say" answer option.

Out of those apartment owners who would agree to make additional payments in order to increase the value of the apartment, $23 \%$ would agree to pay up to 10 euro cents per square meter per month, $29 \%$ would pay up to 20 euro cents per square meter per month, and $20 \%$ of owners would agree to pay more than 20 euro cents per square meter per month. The main reason why people do not want to make additional payments in order to increase the value of the apartment is that they cannot afford it. This reason was mentioned by $43 \%$ of respondents. $31 \%$ of respondents who do not want to make additional payments consider that all the costs of building works carried out to improve the technical condition of the building should be covered by the maintenance fee.

Analysing the respondents' answers on energy consumption and its saving possibilities, it is necessary to evaluate the total energy consumption in Latvia in 2015.

Total energy consumption includes the energy consumption for heat and electricity production (conversion sector) and final consumption, which includes all sectors of the economy as well as households. In Latvia, total energy consumption was 188.7 petajoules $(\mathrm{PJ})$ in 2015.

In Latvia, in 2015 the end-use of energy was $168.5 \mathrm{PJ}$, which was $1.2 \%$ higher than in 2014. Households and transport sector are the largest energy consumers, which consume an average of $30 \%$ of energy. It was observed that energy consumption in households decreased from 63 PJ in 2005 to $50.5 \mathrm{PJ}$ in 2015. (Central Statistical Bureau of Latvia, 2016)

The respondents' answers to the question "Are you interested in total energy consumption of the building and energy saving opportunities?" demonstrate that, in general, about a half or $52 \%$ of survey participants have recognised that they are interested in energy consumption of the building, i.e., $21 \%$ of respondents demonstrate active interest and are trying to save, while $23 \%$ monitor the situation but do not do anything to save; $1 / 3$ of the respondents have indicated that they do not care about it, because it does not matter to them.

In turn, the answers to the question related to activities carried out by Riga residents to save energy demonstrate that the majority of respondents turn the lights off in rooms, which are not used $(86 \%)$, do not leave the water running if not necessary $(86 \%)$ and do not leave the tap running in the apartment $(72 \%)$; slightly more than a half of the respondents $(56 \%)$ try to make good use of household electrical equipment, take a shower rather than a bath and seal windows in the 
apartment. In a similar survey carried out in 2005 the affirmative answers to this question were given by $45 \%$ of respondents.

More than a half of respondents $(52 \%)$ try to save energy resources and keep track of the readings of consumption meters (electricity, hot and cold water), as well as use the opportunity to lower the temperature in the room by means of thermostats at a time when the room is not used.

Energy efficiency, by definition, means the efficient use of energy. To reduce energy consumption of the building, it is necessary to understand what heat losses should be compensated, why they occur and what energy efficiency measures should be taken. Since each building is unique, the energy efficiency measures for each building will differ.

According to the Law on the Energy Performance of Buildings, the building energy efficiency is the relative amount of energy that characterises the energy consumption required for heating, ventilation, cooling, lighting and hot water supply of a particular building under building type-specific operating conditions. Building energy efficiency is expressed in kilowatt-hours per square meter per year $\left(\mathrm{kWh} / \mathrm{m}^{2}\right.$ per year $)$.

Energy efficiency is the ratio of the resulting product or service and the energy consumed. In turn, the improvement of energy efficiency means improved energy efficiency as a result of technological, end-user or economic activities.

Renovation or capital repairs, implementing technical and operational improvements of the building, is one of the most important measures in promoting energy efficiency in buildings. (Seo, Tucker, Ambrose, Mitchell, \& Wang, 2005).

The question then arises as to what people understand by the concept of building energy efficiency. In a similar survey carried out in 2005, respondents had the opportunity to freely (without response options offered) express their views on the building energy efficiency. The answers provided by all respondents were summarised and grouped into several groups. The obtained results demonstrated that, in general, most respondents considered that energy efficiency was economiclefficient use of resources (33\%), $8 \%$ of respondents understood energy efficiency as building insulation, $8 \%$ - a good technical condition of the building and its maintenance, $5 \%$ - no or negligible loss of resources, $4 \%$ - heating system/its improvement, modernisation; other responses were given by $1 \%$ of respondents. It should be noted that $42 \%$ of respondents did not provide specific answers to this question.

In the survey carried out in 2016 , the concept "building energy efficiency" is understood by $50 \%$ of respondents as "efficient heat utilisation", $13 \%$ of respondents imply "saving of resources", $12 \%$ of respondents - "building renovation, insulation". During the period from 2005 to 2016, significant changes have been observed in the citizens' awareness of the concept of "building energy efficiency". In the survey carried out in 2016, only 64 respondents $(0.2 \%)$ answered with "difficult to say, do not understand".

In the survey carried out in 2005 , the respondents were asked to choose from the list of activities that, in their opinion, were related to energy efficiency raising measures. The following measures were frequently mentioned: the insulation of end 
walls $(61 \%)$, replacement of windows $(59 \%)$, insulation of side walls $(57 \%)$, replacement or modernisation of the building heating system (56\%).

In the survey carried out in 2016, the respondents were also asked to choose from the list of activities that, in their opinion, were related to energy efficiency raising measures. The following measures were mentioned: the insulation of end walls (73\%), replacement of windows $(71 \%)$, insulation of side walls $(66 \%)$, the adjustment of individual heating energy consumption and its consumption metering in the apartment (61\%), replacement or modernisation of the building heating system $(60 \%)$.

In the survey carried out in 2016 , only $40 \%$ of respondents provided the affirmative answer to the question whether they were aware of the results of energy efficiency improvement measures, while $56 \%$ of respondents provided the answer "no" to the question whether they were interested in the results of renovated building projects in Riga, $21 \%$ of respondents approved their interest in the results of these projects, while $21 \%$ of respondents did not answer at all.

When asked whether major repairs or improvement works were carried out in their residential buildings during the last 20 (10) years, $45 \%$ of respondents provided answer "no", $29 \%$ of respondents answered with "difficult to say" and only $21 \%$ of respondents answered affirmatively., The respondents mentioned the following contributing factors that may make them engage in the renovation project of their own building: lower apartment fee $(48 \%)$, reduced heating energy costs (43\%), improvement of technical condition of the building (34\%) and improvement of the visual appearance of the building (39\%).

In the survey, there was also a question about additional circumstances promoting implementation of renovation and energy efficiency improvement measures in a residential building; the most common answer to the question above was "the visual appearance of a building is miserable" (67\%), which was followed by the following answer - "renovation works professionally carried out will save half of the heating energy consumption" (50\%).

When the respondents were asked to specify the reasons for not participating in building renovation projects, the most common answer was "I cannot afford it because payments will be higher after renovation" (42\%). When indicating the reasons why no renovation projects were implemented in a particular building, the most common answer was "owners of the apartments have not learned to be hosts of their own building" ( $28 \%$ ), "lack of appropriate renovation offer for tenants of the building" (24\%).

Analysing the answers to the question on the state and local government support for the building renovation projects, it can be concluded that most respondents (39\%) mentioned financial support amounting to at least $50 \%$ and quality assurance of construction works at the level of laws and regulations (34\%). $27 \%$ of respondents provided an affirmative answer to the question on the use of professional energy services, if the energy service company guaranteed the monthly payment that would be less than the former and guaranteed the quality of construction works. 


\section{CONCLUSION}

In Latvia, the majority of residents live in three- or more-family standard residential buildings, which were constructed between 1950 and 1992. These buildings account for more than $10 \%$ of housing stock. At present, these buildings are obsolete; besides, in the course of construction process the durability and reliability levels were planned to be insufficient. In Riga, where there are more than 6,000 standard multi-storey residential buildings, residents specifically do not support building renovation and are passive, despite the availability of the EU and government support as well as co-financing for building renovation projects. Under Latvian climate conditions, a dwelling is one of the main basic necessities. However, the prevailing view of the owners of apartments in the residential building is that the state of the residential building is not their responsibility but rather the responsibility of a third party. Although the privatisation of multi-apartment buildings had been completed more than ten years ago, momentum thinking remained from the time when the apartment and the building as a whole were not a family property.

The apartment and co-ownership share of the multi-apartment building in most cases is the largest property, greatest material resource of the families living there. It would be understandable if the family budget resources were assigned to conservation of the dwelling as resource and preservation of its use value. However, the results of the survey carried out in 2016 show that this issue is not fully understood, only some respondents "recognise" this concept and an even smaller part of them are ready to invest in the preservation of the technical state of the building, market, use value and elimination of depreciation defects.

3,007 respondents at the age of 18-74 years participated in the survey devoted to the examination of standard multi-apartment buildings in ten different microdistricts of Riga. $56 \%$ of the respondents stated that they had been living in their dwellings for more than 10-20 years. Besides, $32 \%$ of respondents were children at the age up to 16 years, while $50 \%$ of respondents had higher education. It should be mentioned that $42 \%$ of respondents were white collar employees, entrepreneurs or senior managers. More importantly, $33 \%$ of respondents had a monthly income of 351 EUR or more per family member.

The majority of respondents assume that the apartment is the most significant asset of the family. Moreover, 34\%-69\% of respondents have renovated their apartment and save resources (electrical energy, water and heating energy) within their apartment boundaries. Only some respondents evaluate the technical condition of communal property, but most respondents do not have information concerning resource supply and energy accounting as well as are not interested in resource saving possibilities within the building in general, and do not understand the importance of technical maintenance of the building.

Additionally, $88 \%$ of respondents consider that the central task of the building management and maintenance is sanitary maintenance of communal facilities of the building, rather than building development, such as refurbishment and renovation, as well as elimination of depreciation, energy efficiency improvement measures. 
Only $25 \%$ of respondents are ready to make savings for the renovation of communal facilities and energy efficiency improvement of a building. On the other hand, since 2005, when a similar research was conducted, the residents' knowledge concerning building energy efficiency has changed noticeably. In $2005,85 \%$ of respondents did not answer the question about their understanding of the concept of building energy efficiency. However, in 2016, $50 \%$ of respondents considered that the reduced consumption of building thermal energy was the most significant aspect in the building energy efficiency improvement process.

Tenants of standard multi-storey residential buildings understand the need for building renovation and energy efficiency improvement; however, there is an obvious lack of knowledge concerning cooperation opportunities within the community of owners of multi-storey residential building as well as organization and management of building renovation projects. Thus, the cooperation between the management company of standard residential buildings and residents is vital to develop comprehensive understanding of building renovation and energy efficiency issues in the community. Finally, the integration of building renovation projects in the building maintenance and management programme is the key aspect.

\section{ACKNOWLEDGMENT}

The present research has been supported by the financial instrument of European Economic Area within the project "Klimata ietekmes, pielāgošanos klimata pārmain̄ām un pielāgošanās iespēju sociāli ekonomisko vērtību novērtējums daudzdzīvokḷu kvartālos Rīgā un Latvijā" ("Rīgas daudzdzìvokl̦ namu mikrorajonu ilgtspējīga attīstība”). ("Evaluation of the Socio-Economic Values of Impact of Climate Changes and the Flexibility of Adaptation to Climate Changes in Residential Quarters in Riga and Latvia" ("Sustainable Development of Multi-Apartment Buildings in Riga Micro-Districts")).

\section{REFERENCES}

Abdulai, R. T., Obeng-Odoom, F., Ochieng, E., \& Maliene, V. (Eds.). (2016). Real Estate, Construction and Economic Development in Emerging Market Economies. Routledge Studies in International Real Estate. New York, NY: Routledge, 404 p.

Ali, H. H. \& Nsairat S. F. A. (2009). Developing a green building assessment tool for developing countries - Case of Jordan. Building and Environment, 44(5), 1053-1064 https://doi.org/10.1016/j.buildenv.2008.07.015

Central Statistical Bureau of Latvia [Latvijas centrālās statistikas pārvaldes portāls]. (2016). Statistic Database. [Palielinās atjaun̄̄go energoresursu īpatsvars pārveidošanas sektorā]. Retrieved June 20, 2016, from http://www.csb.gov.lv/en/notikumi/transformation-sector-showsincrease-share-renewables-44046.html.html [in Latvian]

Chau, C. K., Tse, M. S., \& Chung, K. Y. (2010). A choice experiment to estimate the effect of green experience on preferences and willingness-to-pay for green building attributes. Building and Environment, 45(11), 2553-2561. https://doi.org/10.1016/j.buildenv.2010.05.017

Cole, R. J. (2005). Building environmental assessment methods: redefining intentions and roles. Building Research \& Information, 35(5), 455-467.

https://doi.org/10.1080/09613210500219063 
Diaz-Sarachaga, J. M., Jato-Espino, D., Alsulami, B., \& Castro-Fresno, D. (2016). Evaluation of existing sustainable infrastructure rating systems for their application in developing countries. Ecological Indicators, 71, 491-502. https://doi.org/10.1016/j.ecolind.2016.07.033

Ding, G. K. C. (2008). Sustainable construction - The role of environmental assessment tools. Journal of Environmental Management, 86(3), 451-464. https://doi.org/10.1016/j.jenvman.2006.12.025

Engel, U., Jann, B., Lynn, P., Scherpenzeel, A., \& Sturgis, P. (2014). Improving Survey Methods: Lessons from Recent Research. New York, NY: Routledge.

Geipele, S., Geipele, I., Slava, D., \& Stamure, I. (2012). Social, economic and legal problems of housing management in Latvia. 7th International Scientific Conference Business and Management. 2012. Selected Papers, (pp. 631-638). Lithuania, Vilnius, May 10-11, 2012. https://doi.org/10.3846/bm.2012.082

Kibert, C. J. (2012). Sustainable Construction: Green Building Design and Delivery. John Wiley $\&$ Sons, $560 \mathrm{p}$.

Lavasani, H., \& Werner, A. (2012). Practicality and Sustainability of Using HVFA for Concrete Sidewalks. Construction Research Congress 2012, (pp. 1931-1940). West Lafayette, Indiana, United States, May 21-23, 2012. https://doi.org/10.1061/9780784412329.194

Legislation of the Republic of Latvia. (2015). Dzīvojamo māju pārvaldī̌sanas likums. [Law On Administration of Residential Houses]. Retrieved February 2, 2016, from http://likumi.lv/ta/id/193573-dzivojamo-maju-parvaldisanas-likums

Sarsby, R., \& Meggyes, T. (Eds.). (2009). Construction for a Sustainable Environment. CRC Press, $538 \mathrm{p}$.

Seo, S., Tucker, S., Ambrose, M., Mitchell, P., \& Wang, C. H. (2005). Technical Evaluation of Environmental Assessment Rating Tools, Research and Development Corporation, Project No. PN05.1019, from http://www.fwpa.com.au/images/marketaccess/PN05.1019.pdf.

State Land Service of the Republic of Latvia [Valsts Zemes dienests]. (2016). Latvijas Republikas būvju pārskats 2015. [in Latvian]

Stāmure, I., Kamola, L., \& Geipele, I. (2015). Practical Aspects of Sustainable Construction in Latvia. In 5th International Conference on Industrial Engineering and Operations Management, (pp. 2041-2048). United Arab Emirates, Dubai, March 3-5, 2015. Dubai: IEOM Society. https://doi.org/10.1109/IEOM.2015.7093926

Tambovceva, T., Geipele, I., \& Geipele, S. (2012). Sustainable Building in Latvia: Development and Future Challenges. In ISEE 2012 Conference - Ecological Economics and Rio+20: Abstracts and Full Papers "Sustainable Building, Green Building, Green Building Assessment, Sustainable Development", Brasil, Rio de Janeiro, June 16-19, 2012. Rio de Janeiro: International Society for Ecological Economics - ISEE.

\section{AUTHORS' SHORT BIOGRAPHIES}

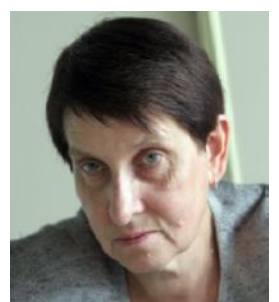

Laimdota Šnīdere is an Asistant Professor, Researcher at the Faculty of Engineering Economics and Management, Institute of Civil Engineering and Real Estate Economics at Riga Technical University (RTU), Latvia. She holds the Doctoral Degree in Physics. She is the author and co-author of scientific publications. Her current research interests are focused on sustainability development problems of energy effiency, construction industry, including land use management and institutional economics. 


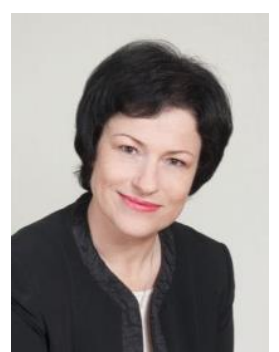

Ineta Geipele is a Professor of the Faculty of Engineering Economics and Management, Director of the Institute of Civil Engineering and Real Estate Economics, the Head of the Department of the Civil Construction and Real Estate Economics and Management at Riga Technical University, Latvia. She improved her professional skills in Austria, Germany, Denmark and the UK. Ineta Geipele is the author and co-author of more than 300 scientific publications. Her current research areas are sustainability development problems of real estate market, construction industry, land use management and institutional economics. Professor Ineta Geipele is an expert of the Latvian Academy of Sciences in Management and Economics Sciences at the Latvian Council of Science, a board member of the FIABCI-Baltic Multinational Chapter and of the Cunfte of the Facility Management of Latvian Housing, and a member of the Latvian Union of Civil Engineers.

ORCID iD: http://orcid.org/0000-0002-2963-087X

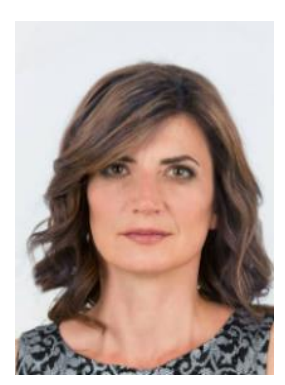

Iveta Stāmure is a Doctoral student, Researcher of the Faculty of Engineering Economics and Management, Institute of Civil Engineering and Real Estate Economics at Riga Technical University (RTU), Latvia. She has obtained the Professional Master Degree in Civil Construction and Real Estate Management and qualification of Real Estate Manager. She is a co-author of scientific publications, two monographs "Models of Financing of Housing Fund Renovation in Latvia" (2012), "Socio-Economic Aspects of the Interaction of Urban and Regional Development" (2012). Her research areas are sustainability development problems of real estate market, construction industry, including land use management and institutional economics, etc. She is a member of the Cunfte of the Facility Management of Latvian Housing and a member of Youth Division of the Latvian Union of Civil Engineers. In 2013 - RTU Gold Fund graduate. In spring 2013 - FIABCI (International Real Estate Federation) grantee.

ORCID iD: http://orcid.org/0000-0002-2963-087X 